Article

\title{
State Control Versus Hybrid Land Markets: Planning and Urban Development in Transitional Hanoi, Vietnam
}

\author{
Hoang Linh Nguyen * (D), Jin Duan * and Jin Hua Liu ${ }^{\mathbb{D}}$ \\ School of Architecture, Southeast University, Department of Urban Planning, No.2 Sipailou Road, \\ Nanjing 210096, China; urband@163.com \\ * Correspondence: hoanglinh2739@gmail.com (H.L.N.); seduanjin@263.net (J.D.); Tel.: +86-0258-379-4226 (J.D.) \\ Received: 19 June 2018; Accepted: 21 August 2018; Published: 23 August 2018 \\ check for
updates
}

\begin{abstract}
During the post-reform period since 1986, land-use systems in Vietnam have been reformed in terms of the regulation of land markets and the built environment. This study analyzes the changing role of urban planning and the policy of state intervention in land markets to manage spatial changes in Vietnamese cities. Theoretical and empirical approaches are used to analyze urban development and planning practices in Hanoi. The study further describes the constraints of planning systems in hybrid land markets that include both formal and informal land development. We argue that in Vietnam, where the role of the state in market construction has not been fully developed and land market institutions are incomplete, urban planning is used as a passive tool of state control and is no longer relevant to the process of spatial development, which is driven by the speculative activities of interest actors. This situation challenges state regulations for the effective management of spatial resources. The empirical results suggest the utility of further reforms to the land-use system and planning institutions in Vietnam, and of strengthening the capacity of the state in land administration.
\end{abstract}

Keywords: urban development; planning control; land market; the state; Hanoi

\section{Introduction}

The Doi Moi program of economic and political reform, which began in 1986, led to an institutional transition from central control to a socialist-oriented market economy. In its transitional phase, the Vietnamese party state on the one hand gradually opened up the market to attract capital, and on the other hand promoted the process of administrative decentralization. These changes profoundly altered the relationship between the state and the market in Vietnam, and market instruments were selectively introduced to supplement the state economy. Since then, the rapid pace of marketization and commodification in the land and housing field have had an immense impact on the built environment of Vietnam's cities, which has created an urgent need to upgrade the urban planning system to govern emerging land markets. Some aspects of the urban planning system, including planning techniques, planning legislation, and the role of planning within development processes, have received increasing scholarly attention [1-6]. Some researchers have conducted critical reviews, which note the inability of current planning techniques and mechanisms to guide and control spatial changes in cities $[1,3,4]$. There have been calls for additional reforms to urban planning and management to address the challenges of the new market-based system [1,5]. However, few studies have adequately analyzed the ideology of the state's control of recent planning reform, or examined the impact of land markets on planning implementation. Some questions must be fully investigated: How is urban planning reformed in Vietnam, and what is the role of planning in facilitating and coordinating land markets? Why does urban planning have a limited practical impact? And how does spatial development influence planning practices? 
This study addresses these questions in the context of the urban transformation of Hanoi, the capital of Vietnam. It elaborates the hybrid character of land markets and spatial production activities, which involve multiple players in both formal and informal manners. By focusing on recent changes to the planning system, we examine the ideology of the state regarding land-use control, and the role of public and private actors in urban construction and the use of planning in Hanoi.

An institutional perspective is adopted to explain land development activities in Hanoi, and analyze urban construction cases in the Ha Dong district. These case studies illustrate the growing coalitions for planned development projects, which are composed of local governments and developers. Spontaneous land and housing transactions among individuals, households, and migrants constantly challenge urban planning in practice. It is found that in the context of Vietnamese cities, where the state is absent in creating market order and the land-use system remains incomplete, planning as a tool of state control is ineffective in hybrid land markets, which are driven by interest actors. This study suggests that further reform of the land-use system and planning institutions in Vietnam is needed to create a more transparent, accountable, and market-determined orientation.

\section{Locality and Methods}

This study draws on the empirical literature on Hanoi's urban development. Hanoi is the second largest city in Vietnam, with a population of approximately seven million people and an area of $3344 \mathrm{~km}^{2}$, as of 2017. As the political capital, Hanoi benefits from central government policies that support economic growth and help to develop its image as a world city. The city government has ambitions for spatial expansion, and for domestic and foreign investments to support urban growth. As a result, the city has undergone a radical extension in recent decades, and its urban area has rapidly expanded into peripheral regions of the city. The present analysis was conducted at both municipal and district levels. At the municipal level, a qualitative analysis was applied to investigate urban transformation during a political-economic transition, including the emergence of land markets and changes in the planning system.

At the district level, Ha Dong was selected as the research area for this study. In recent years, Ha Dong has been the fastest growing district in the urban fringe of Hanoi. It is located on the development axis in the southwest of Hanoi, approximately $10 \mathrm{~km}$ from the historic districts, and is intended to become a multifunctional sub-center that will reduce pressure on the growing population in the city center (Figure 1). Under an incentive program of the city government, investment capital has flowed into property projects in Ha Dong. Once an agricultural district, the urban landscape of Ha Dong is rapidly changing through the development of new urban areas (NUAs) and the initial transformation of peri-urban villages. In this study, we describe the Duong Noi NUA, and Duong Noi village, which are typical examples of formal and informal development in Ha Dong, respectively, and which have received extensive media attention.

The data used in this study were mainly collected during five field visits made to NUAs and urbanizing villages in Ha Dong between September 2015 and October 2017. In total, 11 face-to-face, semi-structured interviews were carried out with key informants, two of whom were researchers at the National University of Engineering (NUE) specializing in urban and regional planning in Vietnam. We also conducted face-to-face interviews with four officials, two of whom are currently working in the Hanoi Department of Planning and Architecture; the other two officials were construction inspectors in Ha Dong district. The experts and officials in the planning department were asked to explain the process of planning reform and planning practice, and the issues related to land-use development in built-transfer and NUA projects. Two local officials from Ha Dong were asked to explain how illegal housing was constructed, what the attitude of the local government was toward this illegal construction, and the number of illegal construction cases in Duong Noi. Additionally, five local residents, who had been living in the Duong Noi NUA for more than one year, were interviewed about their living conditions, and the quality of public services in the projects. In addition to the case 
studies, secondary empirical material, including academic studies, official statistics, planning and policy documents, and newspapers were also collected.

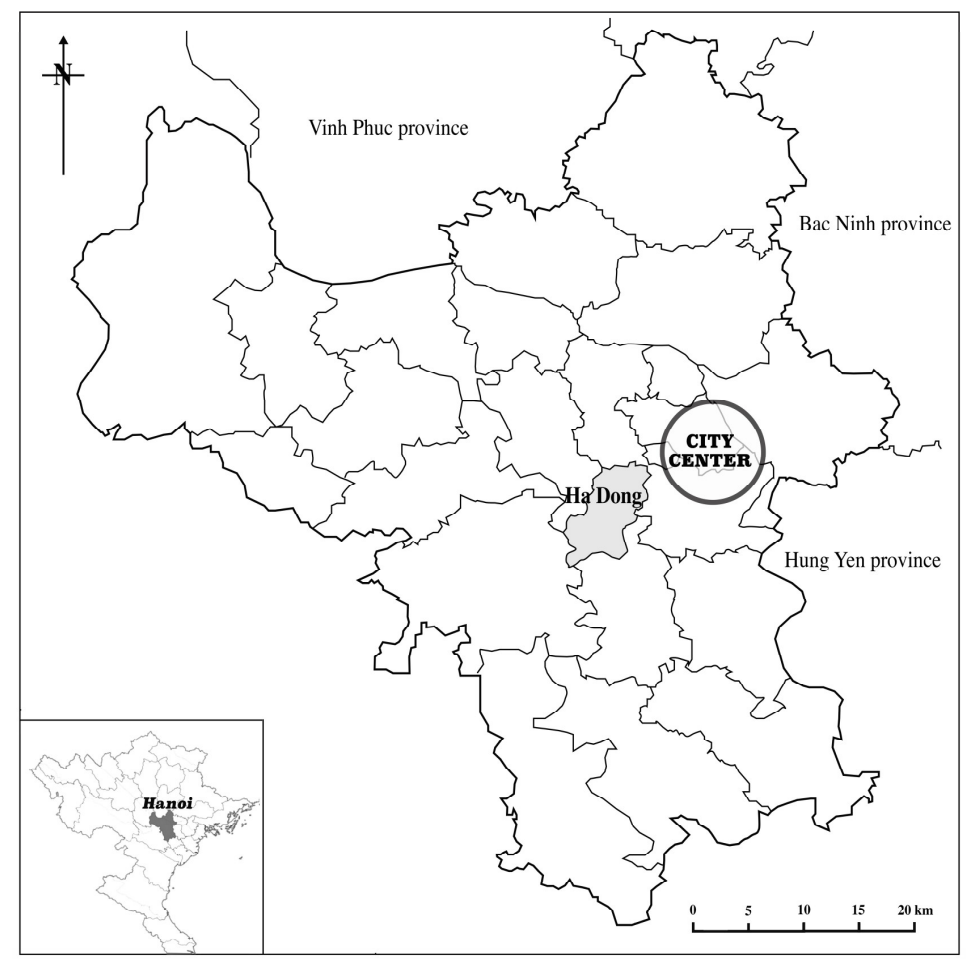

Figure 1. Location of the study area. Source: The authors.

\section{Planning During a Time of Transition: Planning Control and the State Ideology}

\subsection{Conceptual Framework for Urban Planning in Vietnam}

Modern planning dates to the early 20th century, and has been recognized as an important instrument that allows the state to control land and natural resources in Western countries $[7,8]$. Urban planning plays a role in growth management and the physical control of land resources, and provides a platform for the formation of community consensuses on land-use issues [9]. However, the role of planning, which is used by the state as a tool to guide market forces and correct market failures, has been widely debated by researchers from different schools of thought. Urban planning remains essential to the land development process in a market environment [10], and every state in the world exercises public control of urban development through spatial governance and planning [11].

To some Western researchers, the intervention of the state in urban development through planning is understood as a "spatial organization, which facilitates the circulation of capital, commodities, information, etc." [12]. State intervention can prevent externalities related to the land market, and mitigate the negative externalities of the absence of urban welfare in cities [13,14]. Healey and Barrett (1990) claim that the role of the state in the development process is to "moderate the adverse externalities, safeguard social needs and conserve resources and environmental heritage" [15]. The role of planning as an instrument of the state to regulate the built environment considers the social character of the land to be a collective good and a social resource, rather than a mere commodity or private property [16]. However, planning has also been described as a tool of public law, which enables state agencies to acquire property rights for purposes of public interest [17].

In transitional socialist countries, such as China and Vietnam, economic reform has gradually moved towards marketization, but ambiguous boundaries between the state, market, and society enable the state to retain considerable power over new market institutions [18-21]. McGee (2009) argues that urbanization in both China and Vietnam should be seen as a hybrid space production 
process, that has certain characteristics of socialist societies but that includes the market logics of capital circulation and accumulation [18]. In Vietnam, the emergence of property markets involves non-public actors who participate in the construction of the built environment, while the state maintains control over development through policy instruments such as planning, regulation, and land provision [21,22]. While land is a collective asset, a centralized land management system allows the government to manipulate publically-owned land, and planning allows them to manage spatial changes and guide capital investment.

Under the centrally-planned economy, the planning system in Vietnam emphasized the capacity of the central government to plan and control, while local governments had little autonomy in development. Local urban planning was used to implement socioeconomic plans that were decided at higher levels of government. During this period, Vietnam's planning and development model was imported from the Soviet Union, and widely applied at both national and local levels. However, this socialist planning model was very rigid, largely because of command-type decision making and the state monopoly in the distribution of productive resources [23]. As a result, urban planning at the local level was implemented under the supervision and control of the state, while local agencies were required to follow the orders of their superiors.

Since the economic reforms, marketization and political decentralization have become major forces driving the evolution of the urban planning system in Vietnam. Marketization enables the development of the private sector and foreign investment at the local level, which make the local economy less dependent on financial support from the central government. Moreover, decentralization promotes local autonomy and reshapes central-local relationships in administrative authorities, as well as fiscal responsibility. These processes aim to strengthen the independence of the local economy and to ensure the provision of public services [24,25]. Vietnam's post-reform era decentralization process has, on the one hand, shifted responsibilities for the provision of public goods from the central to the local level, and on the other hand has granted local government greater autonomy in finance, planning authorities, and land management. Hence, planning has become an important instrument for local governments to pursue urban growth [21]. In practice, local governments have used planning as a negotiation tool to attain more autonomy from the central government or to attract investment from the private sector [4].

The shift from a planned economy to a market economy has led to the marketization and commodification of housing and land use in Vietnam. These processes have resulted in significant changes in the built environments of Vietnamese cities, in which development is driven both by individuals and interest groups that include businesspeople and local officials. Spontaneous development in Vietnamese cities began during a boom in private housing following economic liberalization $[1,26]$. Subsequently, formal urban development and large-scale planned projects aiming to promote the order and modernity of cityscapes have been launched by governments and enterprises [27]. The urban planning system in Vietnam has been becoming increasingly institutionalized in recent years, paralleling deeper market reforms. There is clearly a need to change the socialist planning mode to a modern planning approach that provides a legal framework with which to regulate spatial development involving multi-interest actors.

Due to the rapid transformation of the urban landscape, urban planning is playing an increasingly important role for local governments in managing development. Due to the top-down system of land administration, local governments require a statutory planning instrument accord for governing and coordinating land markets. However, emerging land markets during the post-reform era, including both informal and formal activities, have become major constraints in planning. The ideology of planning control has been challenged by urban practices, since the local state is not fully present in market construction and to maintain order. This study uses the case of Hanoi to illustrate these issues. In the following section, we examine the changes that have taken place in the planning system both before and after Doi Moi, and discuss the role of urban planning and the intentions of the state in development control. 


\subsection{Urban Planning in the Pre-Reform Era}

Under the centrally-planned economy, civil society in Vietnam was built upon the ability of the state to plan and control. The state monopolized productive resources and strictly controlled labor mobility. Land resources have been nationalized since 1945, and are managed by the state, while the land development process is mainly driven by the public sector, based on a system of administrative land allocation. The non-public sector plays a minimal role in the development process, while the state and its agencies have monopolized city development and urban management. Physical planning departments are responsible for implementing socioeconomic development strategies, which are mandated by related ministries and various sectoral departments. State officials have become actual planners because they have been empowered to propose investments for projects, create development schemes, and make decisions regarding land allocation for specific projects.

During the pre-reform period, Vietnamese authorities adopted a planning and construction model from the Soviet Union, and rejected Western approaches associated with the French colonial era [23]. Urban planning during this period was accomplished with tremendous help from Soviet experts, while industrial and public projects were built with financial and technical support from the Soviet Union and other communist countries. The planning system, which included the national economic plan, physical planning, and other sectoral planning, was highly centralized and based on a top-down structure. Most construction projects were implemented according to physical plans that followed the economic agenda of the state to stimulate industrialization. Physical plans mainly involved selecting sites for industrial and residential construction projects, preparing land reserves for state investment, and organizing transportation networks to connect different economic areas. Under the communist ideology, which prohibits market transactions for land, land resources were allocated by the government to specific users and projects. Without land markets, urban planning played a minimal role in development control, however it provided spatial information and technical support for the implementation of state-led projects.

\subsection{Changes in the Planning System during the Post-Reform Era}

The political economic reforms enacted since Doi Moi have led to significant changes in the legislative system of land use and housing in Vietnam. Since the term 'land-use rights' (LURs) was defined by the Law on Land of 1993, a market for land transactions has emerged alongside the commodification and privatization of urban spaces. With the flow of non-public capital shaping cities, the state has gradually retreated from its dominant position in urban development, for both public services and commercial projects. The urban planning system has evolved to keep pace with the dynamic changes that have taken place in the urban landscape and in state management.

The first policy document related to planning following Doi Moi was Decree No. 91, which was enacted in 1994. Since then, the urban planning system had been divided into two levels: (1) general planning, which involves a 20-year vision for entire cities and their districts; and (2) detailed planning, which focuses on scales of 1:2000 and 1:500. Major problems associated with this planning system include poor coordination among different layers of planning regarding land-use development. At the general planning level, issues related to land-use development are normally overly general, whereas detailed planning focuses only on the physical form of specific projects, and does not consider controlling development at the district or county level. The planning system incorporates two types of detailed planning without clearly distinguishing them in terms of planning tasks, technical methods, or responsibilities for planning organization. Theoretically, developers are only responsible for preparing detailed plans on a scale of 1:500, however in practice they are also required to draft detailed plans on a scale of 1:2000 for improvement projects. In fact, cases in which a local planning bureau has granted permission for projects without the preparation of a detailed plan at a 1:2000 scale are widely observed (interview with experts from NUE, Hanoi, 6 March 2017). While the concept and statutory status of detailed planning at a 1:2000 scale remain ambiguous, local governments do not have an efficient instrument for controlling land development or project approval within their jurisdictions. 
The structure of urban planning in Vietnam has been re-coordinated since the first Law on Urban Planning was established in 2009. This law aimed to strengthen the legal status of the planning system and clearly regulate the roles and responsibilities of each level of government in planning activities, in accordance with a hierarchical administrative structure. Additionally, new planning instruments have been introduced to improve the deficiencies in the previous urban planning system. For example, zoning was introduced to replace detailed planning on a 1:2000 scale, and has become an intermediate level between general and detailed planning. Compared to the latter processes, zoning emphasizes land-use plans at the district level, and the state divides and determines the functions and norms for the use of urban land. Zoning includes the provision of control parameters for the use of each land parcel, and the development of networks for social and technical infrastructure facilities within urban areas. Zoning has thereby strengthened the land management capacities of local governments, and has become the statutory foundation for controlling development in various territories.

In addition to the reform of the planning system, changes in planning legislation have confirmed the state's desire to maintain control over land markets. Local planning bureaus are empowered to either grant planning permits for projects that conform to development plans, or reject projects that do not meet planning requirements. Additionally, land-use plans and detailed local-level planning provide the legal basis for a state-led land-titling program in both the urban and rural sectors. One important precondition for the issuance of an LUR certificate is that construction and land use must comply with regulations regarding local land-use plans and detailed planning (art. no. 101, Law on Land 2013). Planning has become a legitimate instrument of the state that allows it to maintain proactive intervention in land supply. The Law on Land of 2013 states that provincial and municipal governments can reserve land for future development based on local land-use plans that are approved by the central government. This law also mandates that all types of land allocation activities conducted by local governments must comply with approved land-use plans, regardless of whether they are administrative or market oriented (art. no. 52, Law on Land 2013). The content of land-use management has penetrated every level of the contemporary planning system (Figure 2). This planning system interacts with hierarchical land management departments at multiple levels of government and multiple scales of development.

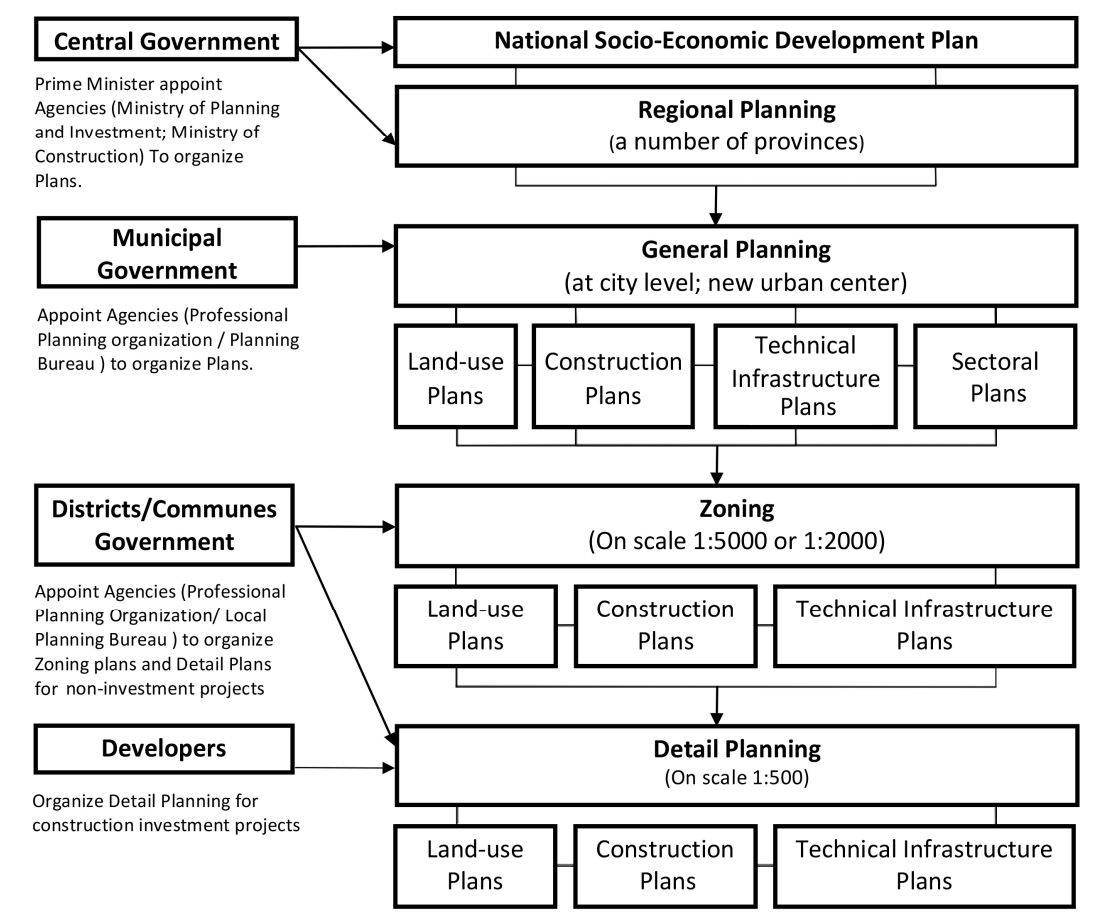

Figure 2. The planning system in Hanoi according to the Law on Urban Planning 2009. Source: The authors. (see Appendix A). 


\section{Urban Development in Transition: Hybrid Land Markets in Hanoi}

\subsection{Spontaneous Development and the Informal Land Market}

Under a centrally-planned economy, the market for land transactions between private users in Vietnam was restricted by the communist state, while housing construction was dominated by the public sector. The government relied on state agencies to construct and distribute low-cost housing among its employees and residents of Hanoi $[26,28]$. However, because of limitations related to the national budget, this housing model failed to satisfy housing demand, and only one third of residents in Hanoi received subsidized housing during this period [29,30].

Due to pressure caused by the housing shortage, in the years immediately following economic reform, the state introduced a policy known as "The State and the People", which encouraged private businesses and individuals to participate in building cities. As a result, the early 1990s saw a boom in housing construction in both urban centers and fringe areas stimulated by individuals, households, and companies [26]. This trend in housing production activities led to tremendous changes in the urban landscape, which were driven by self-built activities, the occupation of agricultural land, modifications to housing blocks, and illegal land transactions [31,32]. This period marked the emergence of informal land markets in Vietnamese cities, and more than $90 \%$ of housing construction in Hanoi was not registered until 1993 [33].

The legal system for land has undergone radical change since the establishment of the Law on Land. In Vietnam, land ownership and LURs are separate. Land is now owned by the people, and governed by the state. LURs are granted by the state to individuals, family households, and organizations, for regulated uses and time spans, which are commoditized and may be transferred between land users. However, land tenure is poorly defined, and the current legal system only recognizes the private ownership of housing and the possession — but not ownership —of land [34]. The land market in Vietnam is a leasehold system of LURs, while land development has become a process involving the capital accumulation of land. Since 1994, the state has operated a land-titling program to legitimize the land market. However, because the capacity of the state is limited in terms of land registration, this program has been slowly implemented in the rural and urban sectors; until 2012, a large proportion of residential land in Hanoi and Ho Chi Minh City still had not been registered (Table 1). Land markets in Vietnamese cities are shaped by the varied legal status of property, and state agencies have attempted to formalize them without granting private ownership outright.

The state's relaxation of the household registration system (ho khau) during the post-reform period prompted the movement of laborers and migrants into Hanoi. In parallel, the city government encouraged the development of new towns and the relocation of industrial sites to peripheral areas, to encourage citizens to move away from the city center. These peri-urban areas have been used as development sites for residential projects and industrial parks. Additionally, large quantities of agricultural land have been converted into urban areas, and rural villages are also increasingly becoming urbanized. Despite the increasing demand for affordable housing, the state provision of public goods (including infrastructure, public amenities, and affordable housing) remains insufficient due to budget constraints. In contrast, unauthorized land transfers and illegal construction activities have contributed to a flourishing informal land market in Hanoi [1,29]. Peri-urban villages have played an important role in the rental housing market, which provides low-cost housing for migrants and low-income groups. Local villagers whose agricultural land was required for urban development engage in self-built activities on their own land and provide rental accommodation for non-native residents. 
Table 1. The completion of the land titling program in Hanoi and Ho Chi Minh city until 2012. Source: Bureau of land management (MONRE). Note: LURCs (Land-Use Rights Certificates).

\begin{tabular}{|c|c|c|c|c|c|c|c|c|c|c|c|c|}
\hline \multirow[t]{2}{*}{ City } & \multicolumn{3}{|c|}{ Agricultural Land } & \multicolumn{3}{|c|}{ Rural Residential Land } & \multicolumn{3}{|c|}{ Urban Residential Land } & \multicolumn{3}{|c|}{ Specialized Land } \\
\hline & $\begin{array}{c}\text { Number of } \\
\text { LURCs Issued }\end{array}$ & $\begin{array}{c}\text { Area } \\
\text { Covered } \\
\text { (ha) }\end{array}$ & $\begin{array}{l}\% \text { of Total } \\
\text { Land Area }\end{array}$ & $\begin{array}{l}\text { Number of } \\
\text { LURCs Issued }\end{array}$ & $\begin{array}{l}\text { Area } \\
\text { Cover } \\
\text { (ha) }\end{array}$ & $\begin{array}{l}\text { \% of Total } \\
\text { Land Area }\end{array}$ & $\begin{array}{c}\text { Number of } \\
\text { LURCs Issued }\end{array}$ & $\begin{array}{c}\text { Area } \\
\text { Covered } \\
\text { (ha) }\end{array}$ & $\begin{array}{l}\% \text { of Total } \\
\text { Land Area }\end{array}$ & $\begin{array}{c}\text { Number of } \\
\text { LURCs Issued }\end{array}$ & $\begin{array}{c}\text { Area } \\
\text { Covered } \\
\text { (ha) }\end{array}$ & $\begin{array}{l}\% \text { of Total } \\
\text { Land Area }\end{array}$ \\
\hline Hanoi & 642,324 & 132,277 & 86.79 & 498,816 & 15,636 & 56.0 & 244,139 & 2634 & 33.89 & 3383 & 8150 & 34.39 \\
\hline Ho Chi Minh & 176,726 & 69,831 & 96.58 & 20,028 & 1463.71 & 19.52 & 555,580 & 6821 & 42.47 & 5239 & 9871 & 64.93 \\
\hline
\end{tabular}


Although the informal land market and illegal construction activities have led to spatial disorder and the failure of planning control, local governments in Hanoi have adopted a tolerant attitude towards these practices, rather than resorting to forced demolition or administrative penalties. The demolition of illegal housing has been generally avoided, other than for the purpose of road widening. In fact, the formalization of informal housing has been undertaken by the state. The Law on Land of 2003 allows households to register houses that were illegally built before July 2004 [35]. In addition to the weak supervision and enforcement capacities of local officials, another explanation for this approach is related to the absence of state provision of public goods, such as social housing for low-income groups. The state has shifted its priority from housing provision to industrial development, and has encouraged the private and semi-private sectors to participate in housing supply [36]. The informal housing market in Hanoi has been seen as a temporary solution to the housing demands of migrants and laborers, and as an important precondition for local industrialization and economic growth [29,37]. However, illegal housing and land transactions make it difficult to create a well-functioning land market with clear property rights, and as a result local revenues from land-related tax collection have decreased. Additionally, excessive construction and land transactions have led to the fragmentation of land use, and have increased population density on land parcels. As the population density in the city center has increased, the amount of land available for urban projects has decreased, and consequently the price of land and the cost of urban projects in Hanoi have both been raised.

\subsection{Planned Urban Projects and the Formal Land Market}

In the 2000s, Hanoi's government started a housing program to attract investment in the development of NUAs. This top-down development process emphasized government enterprise corporations, and has been described as an effort by the state to create disciplined urban landscapes by generating modern, orderly, and functional neighborhoods equipped with basic services and amenities $[26,27,38]$. Beginning with the first generation of NUAs that were constructed by state-owned enterprises (SOEs), the capital received domestic and foreign investment flows into every aspect of its property market. While there is still a large proportion of self-built housing in Hanoi, there has been an increasing trend towards commercial housing and a retreat from housing provision by local governments (Table 2).

Table 2. Housing production over time in Hanoi. Source: Hanoi Statistics Yearbooks (2001-2013).

\begin{tabular}{cccccccc}
\hline Year & $\mathbf{2 0 0 1}$ & $\mathbf{2 0 0 3}$ & $\mathbf{2 0 0 5}$ & $\mathbf{2 0 0 7}$ & $\mathbf{2 0 0 9}$ & $\mathbf{2 0 1 1}$ & $\mathbf{2 0 1 3}$ \\
\hline State-Driven & $12.28 \%$ & $21.75 \%$ & $14.32 \%$ & $12.20 \%$ & $17.66 \%$ & $1.13 \%$ & $2.25 \%$ \\
Self-built & $61.88 \%$ & $48.48 \%$ & $58.68 \%$ & $69.74 \%$ & $59.98 \%$ & $67.27 \%$ & $45.07 \%$ \\
Commercial & $25.84 \%$ & $29.77 \%$ & $27 \%$ & $18.06 \%$ & $22.36 \%$ & $31.6 \%$ & $52.68 \%$ \\
\hline
\end{tabular}

For the provision of infrastructure, the Vietnamese state has adopted a more comprehensive approach to mobilizing private sector investment (through a policy known as huy dong von xa hoi hoa, or public-private partnership), which encourages various capital resources to contribute to the construction of markets and reduces financial pressure on local budgets. Local governments that do not have adequate budgets must rely on international financial aid and private capital to construct public facilities. Thus, the role of local governments in capital investment has become marginalized (Table 3). The public-private partnership model enables local governments to attract private capital for funding infrastructure projects. The land-for-infrastructure mechanism, based on the built-transfer (BT) model, is widely applied in the construction of large-scale infrastructure projects and housing in the peri-urban areas of Hanoi. According to a report on the national inspection of land, 65 megaprojects in Hanoi were launched using the BT model before 2012 (Decision No. 8706, Hanoi). Through this model, governments can use land as a form of payment for the construction of infrastructure and public facilities. When the projects are finished, the government allocates land to the developers instead of cash so that they can invest in commercial projects or commodity housing. These lands are effectively expropriated in the 
name of public projects. In this sense, land resources have become exchange commodities for urban growth, and are seen as tools that local governments can use to negotiate with developers.

Table 3. Fiscal capacity of the Hanoi government. Source: Hanoi Statistic Yearbooks.

\begin{tabular}{cccc}
\hline Year & $\begin{array}{c}\text { Local Government } \\
\text { Revenue as \% of GDP }\end{array}$ & $\begin{array}{c}\text { Budgetary Investment in Capital } \\
\text { Construction as \% of GDP }\end{array}$ & $\begin{array}{c}\text { Budgetary Investment as \% of Total } \\
\text { Investment in Capital Construction }\end{array}$ \\
\hline 1995 & 10.29 & 1.41 & -- \\
2000 & 7.53 & 2.92 & $-\overline{-}$ \\
2005 & 15.25 & 6.82 & 12.18 \\
2010 & 13.78 & 6.65 & 10.48 \\
2015 & 17.80 & 4.73 & \\
\hline
\end{tabular}

Under the current land legislation system, developers in Vietnam can access land in three ways: (1) land allocation through land conveyance methods (including auctions, land bidding, and negotiation) with which developers can access land after paying land-use fees and taxes; (2) the administrative land allocation method, in which land is allocated to developers or users without leasing fees, and which is applied only for specific projects; and (3) land development in transaction markets, in which developers are required to negotiate with the landholder or former developer to purchase their LURs according to negotiated land prices. All types of land development occur under the planning control of the state, and land-use planning permits, land-use certificates, and construction permits are required for investors to develop the land (Figure 3).

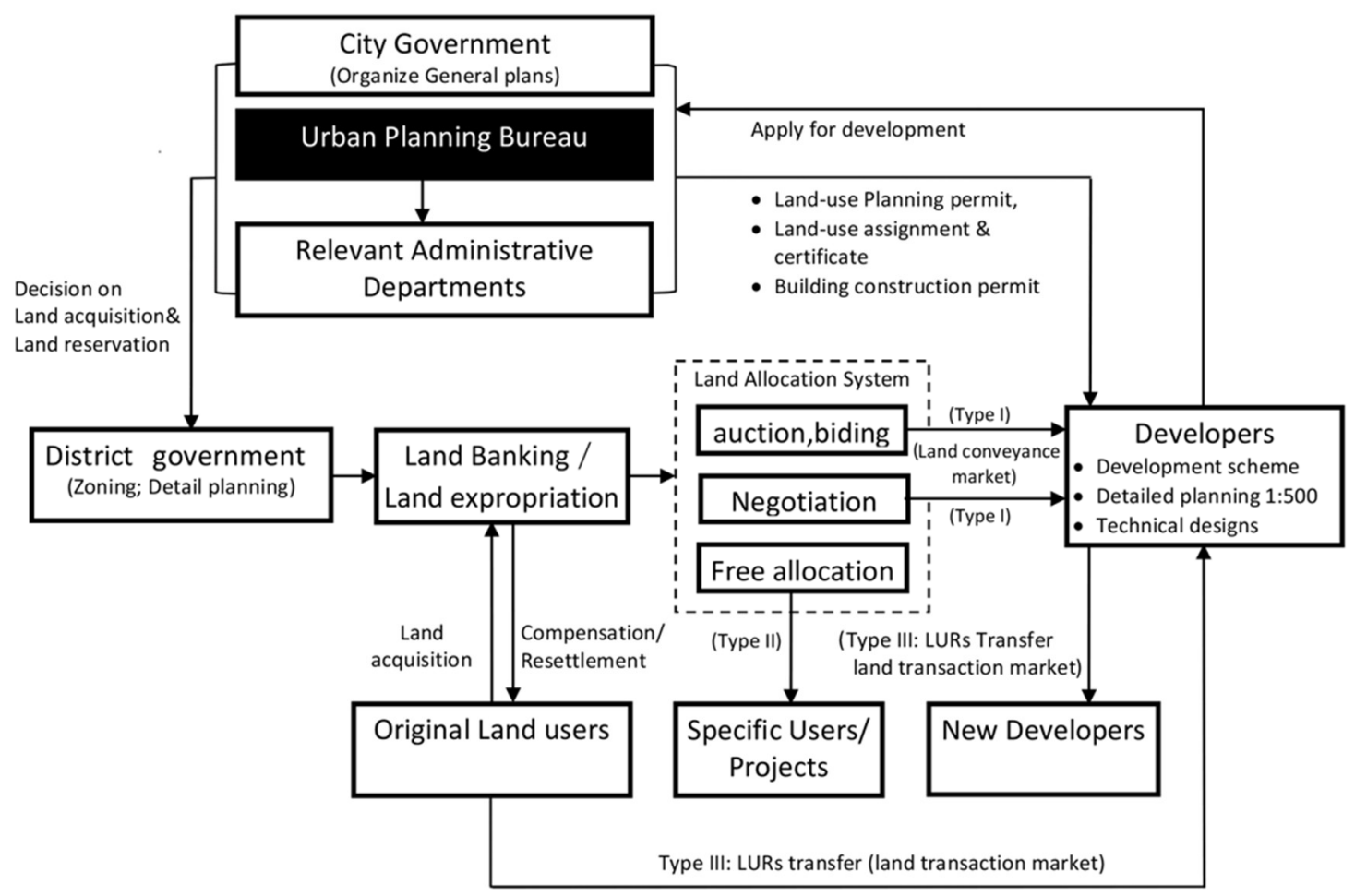

Figure 3. Land development process and planning control in Hanoi. Source: The authors.

\subsection{Hybrid Land Markets Versus Planning Control}

In the post-reform era, the Vietnamese state has made an effort to formalize land markets, through the land-titling program and the establishment of a series of policies seeking to maintain its legitimacy in land markets. Under the current land legislation system, local governments, as the de facto landowners, have been granted power over land management, including responsibility for planning, compulsory land acquisition, and land pricing (Law on Land, 2013). However, this study argues 
that the hybrid character of contemporary land markets in Vietnam is deeply rooted in a dualistic land-use system, that maintains administrative intervention by the state and newly-introduced market institutions. This hybrid land market, with its incomplete market logic, creates opportunities for rent-seeking and speculative behavior, threatening the practical implementation of urban planning.

The dualism inherent in the land-use system was first reflected by the existence of dual land prices that were determined by the state and the market. The Land Pricing Framework (LPF), which was legitimately established by provincial governments, has been widely criticized by researchers and in the Vietnamese media, because official land prices have failed to reflect the market value of land. Some recent studies have found that the state-proposed rates for land appear to be $30-70 \%$ lower than the estimated market values $[39,40]$. However, official land prices in the LPF are used to set up compensation rates for many development projects and projects that use the BT model. This interventionist policy regarding land pricing promotes the growth of coalitions of local elites for two reasons: on the one hand, the policy reduces the cost of compensation for the construction of NUAs and public amenities, and thus promotes the process of urban growth; while on the other hand, the difference in land prices between the market and the administrative tracks creates enormous profits from the land value increase after development, which enables the government and developers to directly benefit from land rents. In this process, the conversion of agricultural land (which has the lowest value in the LPF) into urban areas maximizes the profits of these powerful alliances, and minimizes the cost of development. This situation explains the strong interest of local elites in rural-urban land conversion and their land-rent-seeking behavior in recent years [21,41].

The boundaries of administrative intervention in land acquisition for urban development are very ambiguous. The Law on Land assigns governments significant domain powers over land acquisition for development that aligns with the national and public interest (a concept that is broadly defined). Under current legislation, the state-led construction of high-tech zones, industrial parks, and NUAs ( $k h u$ do thi moi) can all be considered to fall within this scope (art. no. 62, Law on land 2013). Additionally, through the BT model, the government has the innate right to acquire land for the purposes of public interest and then allocate this land to developers for the construction of infrastructure and NUAs. Investors can gain access to land by negotiating land rents with the local government, and benefit from increases in the value of commercial land developments after an infrastructure project has been constructed.

Despite the introduction of land banking and a conveyance system to the law, it has been reported that land allocation in Vietnamese cities does not follow the rules of open competition among market players [31]. According to a random inspection conducted by the central government, land allocation for 14 of 15 projects constructed using the BT model in Hanoi did not follow proper auction and bidding practices (notice no. 2222/TB-TTCP). Additionally, land banking in Hanoi is subject to many constraints due to scarce public financing. According to official data provided by the Land Reserve Centre in Hanoi, only 17.45 ha of land was leased out through auction and bidding methods in 2009, while the total amount of auctioned land was 18.9 ha in 2015. In contrast, a large proportion of land development occurs through the negotiation mechanism. In Vietnam, this is also known as the ask-give mechanism (co che xin cho) in which decisions regarding land allocation and the conditions and fees for land leasing are determined by developers and local governments behind closed doors. This mechanism allows investors to use diplomatic expenses or political relationships to gain advantages in land allocation, which creates opportunities for corruption for local officials in Vietnam [39]. An increasing number of corruption cases related to land management at the local level have been reported in recent years [42-44]. In summary, the dualism of the current land regime has resulted in hybrid land markets in Hanoi and other Vietnamese cities, in which urban projects are driven by growing coalitions of local elites instead of by market demand. This situation has a negative effect on planning control that is analyzed further in the case studies below. 


\section{The Case of Urban Development and Planning in Ha Dong District, Hanoi}

\subsection{Planning Constraints for NUA Projects}

Since the early 2000s, the first round of NUA development in Ha Dong has been completed by SOEs. Prior to 2018, 12 NUA projects, which occupy a total area of approximately 1365 ha, were planned based on the neighborhood unit model (Figure 4). This development model (which includes housing, road systems, public parks, schools, and supermarkets) is a product of the privatization of public amenities, and can therefore be interpreted as a form of responsibility sharing between the private sector and the state regarding the provision of public goods. Private developers, in return, gain privileged access to land resources. For all 12 NUA projects in Ha Dong, developers gained access to land through negotiation or BT rather than by auctions or bidding (Table 4).

The Duong Noi NUA is a typical example of a large-scale project employing the BT model. It is located at the intersection of the fourth ring road and To Huu road in the Ha Dong district (see Figure 3). In 2007, the Nam Cuong Corporation, the investor in the project, was allocated 200 ha of land by the municipal government as payment for the construction of a five-kilometer-long public road, at a total cost of approximately 700 billion VND. This road, which is called Levanluong, was planned as an arterial road connecting the Ha Dong district to the city center, in an effort to boost development in the southwest quadrant of the city.

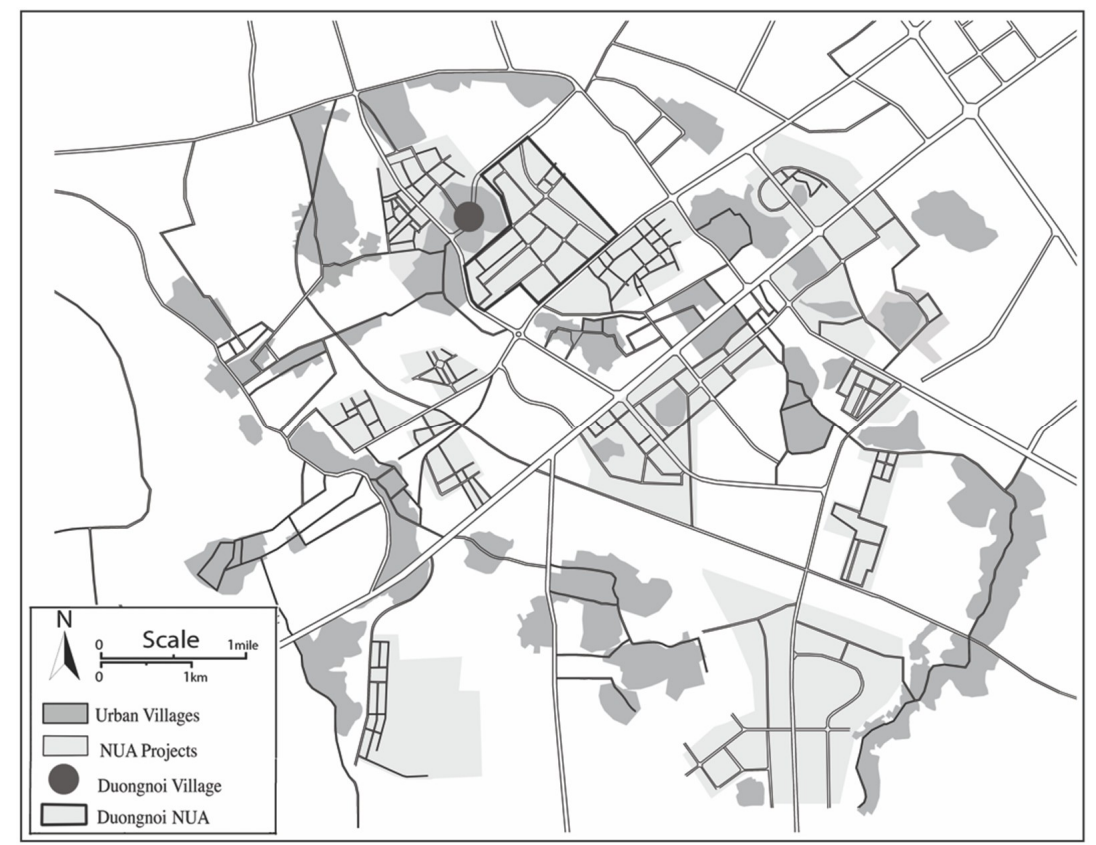

Figure 4. New urban areas and peri-urban villages in Ha Dong district. Source: The authors.

Table 4. Development of new urban area projects in Ha Dong district, Hanoi. Source: Authors' survey.

\begin{tabular}{ccccc}
\hline Name of NUA & Size of Development (ha) & Year & Occupation Rate by Household (\%) & Land Allocation Type \\
\hline Mo Lao & 64 & 2005 & $\geq 90$ & Negotiated \\
Van Quan & 61 & 2003 & $\geq 90$ & Negotiated \\
Van Khe & 23 & 2007 & $\geq 30$ & Negotiated \\
Duong Noi & 200 & 2008 & $\leq 10$ & Built-Transfer \\
Geleximco & 135 & 2007 & $\leq 10$ & Built-Transfer \\
Van Phu & 94.1 & 2007 & $\leq 30$ & Built-Transfer \\
Xa La & 20 & 2008 & $\leq 90$ & Negotiated \\
Thanh Ha & 416 & 2010 & $\leq 30$ & Built-Transfer \\
Kien Hung & 25 & 2008 & $\leq 10$ & Negotiated \\
Phu Luong & 36 & 2009 & $\leq 5$ & Negotiated \\
Đong Mai & 214.8 & 2010 & $\leq 10$ & Negotiated \\
Park city & 77 & & Negotiated \\
\hline
\end{tabular}


According to the detailed plans, the Duong Noi NUA will be transformed from greenfield land into a mixed-use neighborhood intended for a population of 25,000 to 30,000 people. This project was scheduled to be finished in 2013, however after 10 years of construction, the developer has only completed part of the planned development. Some villas have been sold, and one office building has been finished. However, a large amount of land on the site has been kept as greenfield, and the internal road system and other public services, such as the school, park, and supermarket, have not yet been completed (Figure 5). At present, approximately 100 households have moved into the NUA, mostly to the villa area. However, families have to send their children to schools in other wards or surrounding villages, and buy food from street markets (interview with residents in Duong Noi NUA, Hanoi, 23 October 2017).

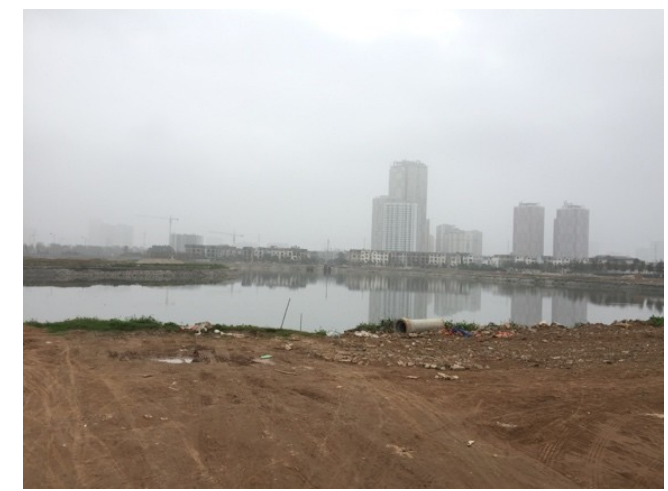

(a)

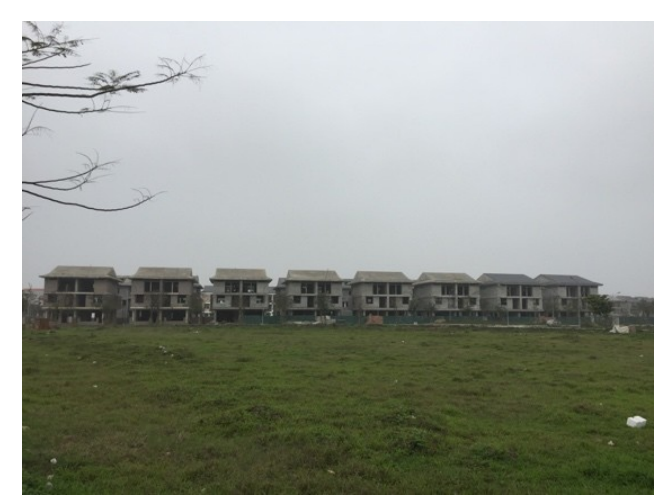

(b)

Figure 5. The Duong Noi new urban area after ten years of construction work. (a) An unfinished public park; and (b) large areas of land in projects remain under construction (copyright: The authors).

In 12 investigated NUAs, there are four projects that use the BT model, which cover a combined area of approximately $845 \mathrm{ha}$, while eight projects have been developed through negotiated land conveyance. Currently, seven NUAs do not have completed internal infrastructure, amenities, or housing, which has caused problems such as land waste and low land-use capability. Current legislation lacks mechanisms with which to evaluate the value of infrastructure projects and reciprocal land acquired for BT projects. The absence of legal mechanisms for accurately evaluating the increasing value of land due to urban projects has been mentioned in previous studies $[45,46]$. Through negotiated land conveyance, developers who obtain land through one-off land allocations gain enormous profits from land redevelopment, without paying development charges and value-added tax to the government.

In the case of Duong Noi, where the government allocated land to the Nam Cuong Corporation, the price of land was originally 8.5 million VND per square meter. However, when the surrounding infrastructure was completed, the price of land increased to between 30 and 40 million VND per square meter (information collected in June 2017). This increase in value is a reasonable explanation for the speculative motivations of property developers to engage in land hoarding in NUAs. Through negotiated conveyance, these developers can obtain land at lower prices than in the competitive market, and subsequently speculate in land when land prices rise.

Real estate developers can additionally obtain large amounts of undeveloped land through the BT mechanism, which is widely applied in Vietnamese cities. For example, the Nam Cuong Corporation has reserved more than 2500 ha of land for six NUA projects in peripheral areas of Hanoi. Similarly, other property developers, such as the Glexemco and Cienco corporations, hold considerable land resources in Hanoi and other Vietnamese cities. Since land that is allocated to developers through "under-the-table" negotiations has a lower price than its estimated market value, developers may choose to hoard the land to obtain speculative profits, rather than construct projects according to the promised schedule. This situation explains why development plans are implemented in segments, 
as well as the large amount of idle land and vacant housing in NUA projects. In practice, many projects in Hanoi have been granted planning permits, and land plots have been sold before the zoning plans had been drafted. Due to this situation, planning is unable to keep pace with urban projects and is hindered by many constraints from previous development. This process has greatly weakened the ability of the state to engage in planning control, while the implementation of approved projects is guided by speculation rather than by market demand.

The commitment of developers to constructing public amenities in NUA projects can be understood as a form of planning gain, to which the developers have to contribute in order to obtain development rights from the government. In practice, this type of public service provision based on planning control is easily violated by developers, because there is no effective enforcement by the government. Indeed, the detailed plans for NUAs, which are approved by local planning departments, are frequently changed. In the case of the Duong Noi NUA, the first detailed plans were approved in 2007, but these plans have been changed three times to increase the profitability of the project. Compared to the first detailed plan, the number of households in the revised detailed plan of 2012 increased from 2797 to 3308 , however, the planning index for public amenities did not change. Negotiations between the local state and developers for planning adjustment are widely observed in Hanoi. In most cases, developers negotiate for taller buildings or larger construction areas, which decrease the amount of public land and increase the commercial area. Commenting on the phenomenon of plan changes for NUA projects, one official at the Department of Planning and Architecture stated the following:

"Most of the NUA projects are applied by the developers according to approved planning. But even when actual developments don't match the planning, the developers will apply for a planning readjustment. In practice, this situation frequently happens. It shows us the fact that urban development is private-led but not state-led. Obviously, this type of development is profit-driven and speculative, they (developers) do not consider the public interests or the real housing demand" (Interview with official in DPA, Hanoi, 8 April 2016).

While fiscally-deficient local state governments have to rely on private capital to meet their development goals, land-use regulation has become a negotiated mechanism used by pro-growth alliances for their mutual benefit. Although the current institutional system empowers local governments to facilitate land markets, in practice they are weaker in these negotiations and often yield to developers' interests. Due to the absence of the state as a third party to enforce market rules, urban planning has failed to provide certainty or protect the legitimate rights of land users in neighborhood development. As a consequence, these projects cannot internalize externalities, which leads to ineffective land use and uncoordinated built environments.

\subsection{Uncontrolled Development in Peri-Urban Villages}

Due to the rapid pace of urbanization, the Ha Dong district has provided land for development projects, including infrastructural and residential construction. To reduce the costs of land acquisition and resettlement, projects are mainly greenfield redevelopments, and developers attempt to avoid developments in existing residential villages. The traditional villages in Ha Dong have been gradually encircled by NUAs. Prior to 2018, there were 37 peri-urban villages in Ha Dong, and 11 of these are now fully surrounded by NUAs.

The spatial organization of these traditional villages is closely tied to the characteristics of an agricultural society with many sociocultural regulations for rural communities. However, the traditional fabric of rural villages is being rapidly destroyed. The lack of effective planning control leads to the construction of self-built housing, and land occupation. Villagers start to construct buildings on their own land, and lease or sell parts of their land to generate revenue. In some villages, such as Mo Lao and Van Quan, villagers provide rental housing to migrants by building mini apartments in narrow alleyways, thereby increasing pressure on the local environment. During the transitional 
period, when formal regulations on the land market were absent, traditional (informal) rules of spatial production were violated by the speculative behavior of individuals.

Before 2008, Duong Noi was an agricultural village. The rapid transformation of this village began during the construction of two NUAs (Duong Noi and Gleximco) in 2007 (see Figure 4). Since that time, Duong Noi has been integrated into the urban structure, and has become a ward of Ha Dong. In 2008 this ward had an area of 585.3 ha, and a population of approximately 17,311 people. In 2014, the population of this ward had increased to 21,000 people, with migrants making up the majority of the new inhabitants. To supply land for two large scale NUA projects, agricultural land surrounding Duong Noi has been converted into urban areas.

Illegal land occupation and unregulated construction have been very common occurrences in Duong Noi. After the government decided to expropriate land for two NUA projects, local farmers started to occupy thousands of square meters of agricultural land, and to repurpose it for other uses or to lease out self-built housing to non-natives. According to the information provided by the officials in Ha Dong, between March 2006 and December 2007, 122 households occupied a total of 14,700 square meters of agricultural land. Between 2007 and May 2008, there were more than 200 cases of occupation. While these illegal activities occurred on a large scale and involved many households, the local government responded passively to the situation. One officer in the Duong Noi ward stated the following:

"They (villagers) think that if numerous families simultaneously occupy the land on a large scale and if they transfer housing to the migrants, the government will not be capable of removing their constructions" (interview with official in Ha Dong, Hanoi, 3 June 2017).

After construction on the NUAs began, Duong Noi village lost its agricultural land. Only a small group of villagers has received new land plots as compensation (these are arranged in a row and are provided with basic services). Most of the villagers received money as compensation. While the original villagers have retained their own houses and courtyards, they now have the opportunity to build small dwellings on their land, and to rent them out to migrants. Some households have divided their courtyards into small plots, before transferring them to others. Since they no longer have agricultural sources of income, local villagers have sought alternative ways to monetize their land holdings, by using their lands and gardens for business purposes, or as rental housing or workplaces. This process has driven the transformation of spaces inside the village through spontaneous construction and land transactions.

Duong Noi is gradually becoming a self-contained peri-urban village. Its spatial territory is bounded by two large-scale projects. In tandem with the flow of migrants into Duong Noi, the village is being restructured and transformed to adapt to its increasing population density. Traditional courtyards are being turned into smaller land plots, and new buildings are higher and narrower. In fact, many buildings do not meet the minimum standard area for housing (30 square meters). In many communities, the distance between adjacent buildings is one meter, and neighbors can shake hands through their windows (Figure 6). The high construction density inside these villages causes problems with ventilation, privacy, fire safety, and the quality of the living environment. The right to be protected from negative neighborhood effects does not exist in these cases, and land development in urbanizing villages has failed to internalize these externalities. Without reliable and effective market institutions, local villagers and migrants become new players in the arena of urban development, and maximize their individual profits, which consequently leads to a substandard physical environment. 


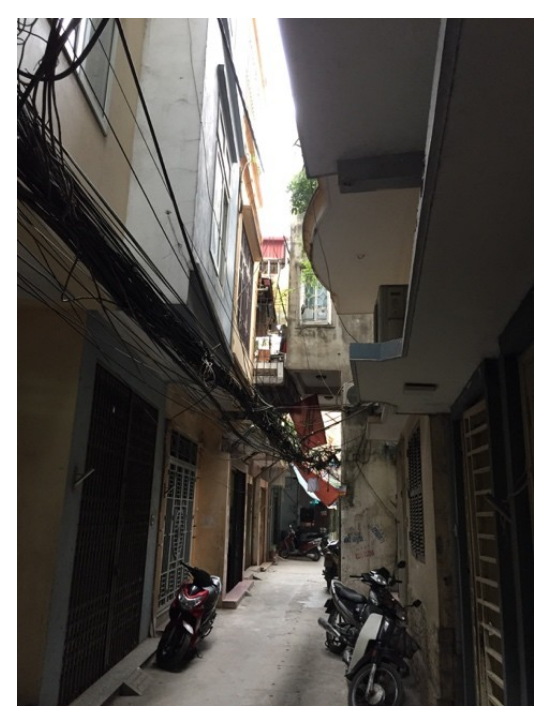

(a)

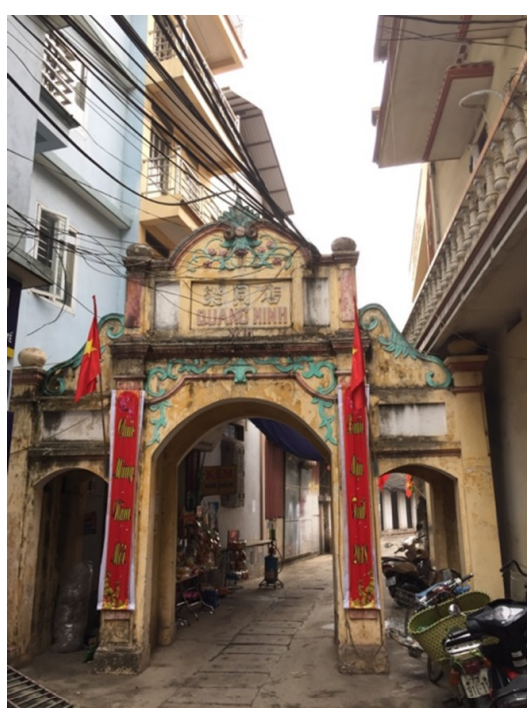

(b)

Figure 6. Buildings in Duong Noi village: (a) new constructions adjacent to the old village gate; and (b) high-density housing inside the village (copyright: The authors).

Peri-urban villages additionally highlight the absence of the state in the provision of planning control and the enforcement of rules for spatial changes. Zoning plans simply set boundaries and development control parameters for the population, as well as for site coverage and building height. Detailed planning is neither carried out in Duong Noi nor in many other peri-urban villages in Ha Dong, despite the government's responsibility for creating detailed plans for these areas. Facing the prospect of informal development in peri-urban villages, the control mechanisms that focus on population, zoning, and building density are not relevant in practice when there is no clear delineation of property rights. Local officials therefore lack effective planning tools to control development and pervasive land transactions in their territories. Informal development rapidly increases both population density and the number of land users on land parcels, and also clearly causes conflicts between landholders regarding the boundaries of properties. This situation creates many difficulties for the land-titling program, and challenges the formal control framework of the state.

\section{Discussion and Conclusions}

This study utilizes case studies in Hanoi to review the emergence and development of the land market since the Doi Moi reforms. From the perspective of institutional changes, it analyzes the evolution of the planning system and land-use policies in Vietnam, thus further advancing the understanding of state-market relations during transition periods. Although the party state has acknowledged the contributions of market forces to urban development, the state ideology of spatial regulation has remained. The state, on the one hand, introduces market mechanisms to facilitate and formalize land markets, and on the other hand maintains intervention in land development. The hybrid nature of the current land system has caused ambiguous boundaries between the state, the market, and society in terms of urban formation, which is expressed in formal or informal land development. This system has produced many opportunities for powerful elites, speculators, and residents to engage in entrepreneurial activities and hinder planning control.

Two cases of land development in the Duong Noi ward have been used to illustrate the above statement. Investment in infrastructure and large-scale residential projects in Ha Dong has been guided by the housing strategy and various preferential policies of the local government. Due to the inability of the local government to provide infrastructure and public facilities, low-cost land allocation has become a major incentive for investment. However, the case of the Duong Noi NUA reveals that developers who control capital investment have the upper hand in negotiations, and that they 
implement their strategies to change, bypass, or weakly enforce planning regulations to increase the profitability of developments. In contrast, local governments lack the financial instruments to capture the profit from land development to reinvest in infrastructure. Hence, the consequences of low-cost land leasing include not only ineffective land development, but also future issues for local budgets, due to the large tracts of land that have been leased out for one-off rental payments.

The informal land market emerged at the end of the 1980s, and continues to flourish because the formal land market and the government have not provided sufficient affordable housing or public services for residents, migrants, and the urban poor. In peri-urban areas, self-built housing and illegal land transactions in urban villages are widely observed, and contribute to the growth of informal markets. However, permitting uncontrolled informal construction is not a sustainable solution for urbanization. The case of Duong Noi village reveals that unregulated construction and land transactions lead to fragmented land holdings and substandard built environments. Although current planning institutions emphasize the role of urban planning in legalizing construction activities, in practice, self-built housing in peri-urban villages is constructed without planning control. Since state and public finance capacities are weak, planning in peri-urban villages is not a priority of the government. Continuous informal development in the peri-urban areas of Hanoi is the result of speculative urbanism caused by the ineffective state regulation of rapid urbanization.

This study provides a broader perspective from which to explain the constraints of planning implementation in actual development. Shifting from a centrally-planned economy to a market economy means that the land development process is no longer dominated by the state, but rather has become an arena with multiple players. During the transition era, local governments are no longer disinterested actors, but are proactive in using their authority over land management to pursue local growth, political promotion, and budgetary income $[21,22,41]$. In practice, the mechanism of "under-the-table" negotiations strengthen the pro-growth coalition of local elites and negatively influences planning processes. The Ha Dong NUAs show how local governments and their partners manipulate land resources and planning controls to archive urban growth and maximize accumulation. Since urban development is driven by those in positions of power and those who control investment capital, land transactions and planning are outside of the planner's control. Therefore, planning control in Vietnam should not be interpreted as a purely technical control process, as it usually is, but rather as a process of mediation and bargaining among interest groups. Thus, the state regulation of spatial development depends not only on adequate planning, but also requires more coordination mechanisms and transparent land administration systems.

This study focuses on urban development in transition-era Hanoi. Our assessment is that the intention of the state in terms of planning control is far from what is expected in the context of hybrid land markets that are driven by non-state actors. We suggest that efforts to enact planning reform in Vietnamese cities should focus on institutional changes, rather than the physical control of the state over urban development. There is an urgent need to reform the land-use and planning institutions of Vietnam to make them transparent, accountable, and market oriented. Local governments should enhance their ability to guide and regulate land markets. The use of low land prices as investment incentives is not a long-term or sustainable strategy. The potential value of land assets can only be fully explored in a market manner (such as through auctions, bidding on land allocations, and the use of property taxes) that would sustainably contribute to local budgets and effectively formalize land markets.

Author Contributions: H.L.N. designed the study, analyzed the data, and wrote the manuscript. J.D. advised on this research from the original idea to the writing. J.H.L. was responsible for data and information collection. All authors have read and approved the manuscript.

Funding: This research received no external funding.

Acknowledgments: The authors would like to thank Guo Qin Zhang and Chu Ngoc Huyen for their helpful comments on an earlier draft.

Conflicts of Interest: The authors declare no conflict of interest. 


\section{Appendix A}

National Socio-Economic Development Plan: The national government formulates five-year plans designed to guide the development of the Vietnamese economy at each specific stage of the revolution. This type of planning is a key characteristic of centralized, communist economies, and one plan established for the entire country normally contains detailed economic development guidelines for all its regions.

General Planning: General planning is the organization of the space and system of technical and social infrastructure facilities and houses for an urban center suitable to its socioeconomic development, ensuring defense, security, and sustainable development. It is made for centrally-run cities, provincial cities, towns, townships, and new urban centers.

Detailed Planning: Detailed planning is the division and determination of norms on the use of planned urban land, requirements for the management of architecture and landscape for each lot of land. It is the arrangement of technical and social infrastructure facilities in order to concretize a zoning plan or general plan.

Detail Planning on a 1:500 scale: Drawings of a detailed plan shall be made on a 1:500 scale. Technical infrastructure, basic design, engineering design, and construction works are arranged for each boundary of the lot. The approved detailed plan serves as the basis for granting construction permits and formulating construction investment projects.

Detail Planning on a 1:2000 scale: Drawings of a detailed plan shall be made on a 1:2000 scale for functional urban quarters, such as industrial parks, hi-tech parks, export processing zones, cultural heritage conservation zones, tourist and recreation resorts, and other identified zones.

Land Auction: The government authorizes an agency to auction recovered land in accordance with the land-use purpose defined in the land-use planning document.

Land Bidding: The government selects the enterprises for a project with an offer for the land in the form of a public-private partnership or investment projects on the basis of a transparent comparison. The winner is the bidder with the highest score awarded to its investment project and the largest amount offered for the land.

Negotiation land allocation: The government directly leases land to selected investors or land users with negotiated land-use fees.

Free land allocation: The administrative land allocation method is used to grant land-use rights to state agencies or other specific users without the collection of land-use fees in Vietnam.

\section{References}

1. Quang, N.; Kammeier, H.D. Changes in the political economy of Vietnam and their impacts on the built environment of Hanoi. Cities 2002, 19, 373-388. [CrossRef]

2. Mai Anh, T.; Kidokoro, T.; Seta, F. Practices of detailed planning in Hanoi city under transition economy uncertainty of detailed planning in Cau giay district. In Proceedings of the 20th International Conference Symposium on City Planning, Sendai, Japan, 23 August 2013; pp. 1-13.

3. Matsumura, S.; Nguyen, T.H.; Truong, T.K. New Approach and Issues for the Urban Planning System in Vietnam-The Practice of the Newly Formulated Urban Planning Regulations in Ho Chi Minh City. Urban Reg. Plan. Rev. 2017, 4, 58-70.

4. Huynh, D. The misuse of urban planning in Ho Chi Minh City. Habitat Int. 2015, 48, 11-19. [CrossRef]

5. Van Horen, B. City profile Hanoi. Cities 2005, 22, 161-173. [CrossRef]

6. Leducq, D.; Scarwell, H. The new Hanoi: Opportunities and challenges for future urban development. Cities 2018, 72, 70-81. [CrossRef]

7. Andersen, J.E.; Jenkins, P.; Nielsen, M. Who plans the African city? A case study of Maputo: Part 1-The structural context. Int. Dev. Plan. Rev. 2015, 37, 331-352. [CrossRef]

8. McAuslan, P. Land, Law and Planning; Weidenfeld and Nicholson: London, UK, 1975.

9. Kaiser, E.J.; Godschalk, D. Twentieth century land use planning: A Stalwart family tree. J. Am. Plan. Assoc. 1995, 61, 365-385. [CrossRef] 
10. Healey, P.; Shaw, T. Changing Meanings of 'Environment' in the British Planning System. Trans. Inst. Br. Geogr. 1994, 19, 425-438. [CrossRef]

11. Janin Rivolin, U. Global crisis and the systems of spatial governance and planning: An European comparison. Eur. Plan. Stud. 2017, 25, 994-1012. [CrossRef]

12. Lamarche, F. Property Development and the Economic Foundations of the Urban Question. In Urban Sociology: Critical Essays; Pickvance, C.G., Ed.; Tavistock Publication: Andover, MA, USA, 1976; pp. 85-118.

13. Harvey, D. Labor, Capital, and Class Struggle around the Built Environment in Advanced Capitalist Societies. Politics Soc. 1976, 6, 265-295. [CrossRef]

14. Caldarice, O. Reconsidering Welfare Policies in Times of Crisis: Perspective for European Cities; Springer: Dordrecht, The Netherlands, 2018.

15. Healey, P.; Barrett, S.M. Structure and agency in land and property development processes: Some ideas for research. Urban Stud. 1990, 27, 89-104. [CrossRef]

16. Foglesong, R. Planning the Capitalist City: The Colonial Era to the 1920s; Princeton University Press: Princeton, NJ, USA, 1986.

17. Needham, B. Planning, Law and Economics: The Rules We Make for Using Land; Routledge: London, UK, 2006.

18. McGee, T.G. Interrogating the production of urban space in China and Vietnam under market socialism. Asia Pac. Viewp. 2009, 50, 228-246. [CrossRef]

19. Gainsbourough, M. Vietnam: Rethinking the State; Zed Books: London, UK, 2010.

20. Zhu, J. Local Developmental State and Order in China's Urban Development during Transition. Int. J. Urban Reg. Res. 2004, 28, 424-447. [CrossRef]

21. Nguyen, H.L.; Duan, J.; Zhang, G.Q. Land Politics under Market Socialism: The State, Land Policies, and Rural-Urban Land Conversion in China and Vietnam. Land 2018, 7, 51. [CrossRef]

22. Labbé, D.; Musil, C. Periurban land redevelopment in Vietnam under market socialism. Urban Stud. 2014, 51, 1146-1161. [CrossRef]

23. Logan, W. Russians on the Red River: The Soviet impact on Hanoi's townscape, 1955-1990. Eur. Asia Stud. 1995, 47, 443-468. [CrossRef]

24. Rao, M.G. Fiscal decentralization in Vietnam: Emerging issues. Hitotsub. J. Econ. 2000, 41, 163-177.

25. World Bank. East Asia Decentralizes: Making Local Government Work; World Bank: Washington, DC, USA, 2005.

26. Gough, K.V.; Tran, H.A. Changing housing policy in Vietnam: Emerging inequalities in a residential area of Hanoi. Cities 2009, 26, 175-186. [CrossRef]

27. Boudreau, J.A.; Gilbert, L.; Labbé, D. Uneven state formalization and peri-urban housing production in Hanoi and Mexico City: Comparative reflections from the global South. Environ. Plan. A 2016, 48, $2383-2401$. [CrossRef]

28. Phe, H.H. Investment in residential property: Taxonomy of home improvers in central Hanoi. Habitat Int. 2002, 26, 471-486. [CrossRef]

29. World Bank. Vietnam Urbanization Review: Technical Assistance Report; World Bank: Washington, DC, USA, 2011.

30. Drakakis-Smith, D.; Dixon, C. Sustainable urbanization in Vietnam. Geoforum 1997, 28, 21-38. [CrossRef]

31. Geertman, S. The Self-Organizing City in Vietnam; Processes of Change and Transformation in Housing in Hanoi. Ph.D. Thesis, Eindhoven University of Technology, Eindhoven, The Netherlands, 2007.

32. Koh, D. Illegal Construction in Hanoi and Hanoi's Ward. Eur. J. East Asian Stud. 2004, 3, 337-369. [CrossRef]

33. Luan, T.D.; Vinh, N.Q. Socio-Economic Impacts of 'Doi Moi' on Urban Housing in Vietnam; Social Sciences Publishing House: Hanoi, Vietnam, 2001.

34. Truong, T.T.; Perera, R. Intermediate levels of property rights and the emerging housing market in Ho Chi Minh City, Vietnam. Land Use Policy 2011, 28, 124-138.

35. Tran, H.A.; Yip, N.M. A regime of informality? "Informal housing" and the state-society relationship in transitional Vietnam. Trialog 123 2017, 4, 20-29.

36. Seo, D.; Kwon, Y. In-Migration and Housing Choice in Ho Chi Minh City: Toward Sustainable Housing Development in Vietnam. Sustainability 2017, 9, 1738. [CrossRef]

37. Leaf, M. Vietnam's Urban Edge: The administration of urban development in Hanoi. Third World Plan. Rev. 1999, 21, 297-315. [CrossRef]

38. Tran, H.A. Urban Space Production in Transition: The Cases of the New Urban Areas of Hanoi. Urban Policy Res. 2015, 33, 79-97. [CrossRef] 
39. Embassy of Denmark; World Bank; Embassy of Sweden. Recognizing and Reducing Corruption Risks in Land Management in Vietnam; The National Political Publishing House: Hanoi, Vietnam, 2011.

40. Truong, T.T.; Perera, R. Consequences of the two-price system for land in the land and housing market in Ho Chi Minh City, Vietnam. Habitat Int. 2011, 35, 30-39.

41. Phuc, N.Q.; Westen, A.C.M.V.; Zoomers, A. Agricultural land for urban development: The process of land conversion in Central Vietnam. Habitat Int. 2014, 41, 1-7. [CrossRef]

42. Vn Express. Vietnam Arrests Top Ex-Officials as Corruption Crackdown Continues. Available online: https:/ /e.vnexpress.net/news/news/vietnam-arrests-top-ex-officials-as-corruption-crackdown-continues3738134.html (accessed on 8 July 2018).

43. Vietnam News. Land Corruption on the Rise: NEU Research. Available online: https:/ /vietnamnews.vn/ society /347664/land-corruption-on-the-rise-neu-research.html (accessed on 10 July 2018).

44. Tuoi Tre News. Build-Transfer Contracts Sow Fertile Ground for Corruption in Vietnam: Conference. Available online: https:/ / tuoitrenews.vn/news/business/20171020/buildtransfer-contracts-sow-fertileground-for-corruption-in-vietnam-conference/42172.html (accessed on 14 July 2018).

45. Nguyen, T.B.; Van der Krabben, E.; Spencer, J.H.; Truong, K.T. Collaborative development: Capturing the public value in private real estate development projects in Ho Chi Minh City, Vietnam. Cities 2017, 68, 104-118. [CrossRef]

46. McCluskey, W.J.; Trinh, H. Property tax reform in Vietnam: Options, direction and evaluation. Land Use Policy 2013, 30, 276-285. [CrossRef]

(C) 2018 by the authors. Licensee MDPI, Basel, Switzerland. This article is an open access article distributed under the terms and conditions of the Creative Commons Attribution (CC BY) license (http:/ / creativecommons.org/licenses/by/4.0/). 